\title{
Special Issue: Research on Textbooks in Science and Mathematics Education
}

The COVID 19 pandemic suddenly turned education upside down, opening up several major questions. One of the pillars they have in common is the need of solid ground, a beacon which would navigate learning on the suddenly stormy educational waters. Soon after the schools were closed (for the first time), teachers started to look for materials in various social media outlets. It almost seemed that, at that instant, the intended materials for face-to-face teaching were not sufficient enough. Several highlyadaptable teachers gained popularity with their educational videos, many shared their slides and looked for others. Almost as if they were not equipped with the most-spread educational tool - textbooks.

This could be due to teachers' effort to diversify home learning for their students. However, this could also be an indicator of teachers' attitude towards textbooks as far as students' activation is concerned. There is a significant body of research showing textbooks are still a very influential agent in education: they represent a translation of the curriculum for many teachers (Chiappetta \& Fillman, 2007), are the main source of information (cf. Mullis et al., 2012) or analogies (Harrison, 2001) for teachers and even a subscription of lesson content including methods (Lepik et al., 2015; Mullis et al., 2012). Yet, information about the use of textbooks for student activation show a rather reserved trend. Son and Kim (2015) reported teachers providing their students with tasks of a lower cognitive difficulty and even splitting more demanding tasks for their students, thus depriving them of the possibility to develop certain skills or thinking patterns. Vojiř and Rusek (2021) found teachers building their lessons based on simplified texts and graphics rather than sets of tasks.

The teachers' behaviour, however, might suggest textbooks serve as good material for in-school lectures but do not serve as good materials for distance teaching. This brings more serious questions: Are textbooks suitable for contemporary students' independent learning? Is the text adequate (comprehensible, readable, structured)? Are the visual components self-explanatory enough? Or do students need a guide (teacher) to help them study from the book?

The uncalled-for opportunity to re-evaluate settled teaching practices and educational tools also highlighted the role of textbooks. For this reason, Scientia in educatione opened a call for a special issue to bring forward research on the role of textbooks in science and mathematics.

Papers included in the special issue target chemistry, biology and mathematics textbooks. Three papers submitted a textbook segment to a thorough evaluation. Zupanc and Devetak looked into electrolyte chemistry pictorial materials used in Slovenian lower-secondary chemistry textbooks. Representations are one of the most important topics within chemistry education research due to their potential to mediate abstract phenomena to students in a more comprehensive way (Johnstone, 1991; Taber, 2013; Talanquer, 2011). With only a limited segment to be seen by the naked eye in electrolyte chemistry (not only there), macroscopic representations need to be accompanied by micro and symbolic representations. Naturally, modern technologies also offer comprehensive hybrid representation constructions. The presented study, however, showed sub-microscopic and hybrid representations to be the least common in the analysed textbooks. This is in accordance with research by Šubová (2020) from the Czech environment, which points to a possible global trend in chemistry subject-matter representation.

Another type of representation, this time in biology - diagrams - was analysed in Machová's study. As shown in other research (e.g. Dees et al., 2014; Halverson et al., 2011), many students (even university students) hold misconceptions as far as phylogenetic trees are concerned. Learning materials' analysis is therefore a logical step towards improvement. Czech biology textbooks for secondary schools were submitted to an analysis of phylogenetic trees' characteristics. Evolutionary diagrams were evaluated according to the cladistics. The results showed almost a half of the analysed diagrams do not support the current scientific understanding of evolution, putting stress on ladder thinking and, in the majority of cases, lacked scaffolding which would lead students to reading the diagrams successfully. As shown by Jian (2021), when provided appropriate instruction, students focus more on the text in diagrams, and therefore learn. Similar to Zupanc and Devetak's paper, Machová concluded her paper with several suggestions for new textbooks or contemporary textbook improvements.

Zenkl's study, on the other hand, focused on the above-mentioned textbooks' role in supporting teachers. His paper focused on presenting combinatorial concepts and its compliance with a concept development theory in secondary school mathematics textbooks. It was built on the theory of generic models (Hejný, 2012) aimed at selected combinatorial concepts and procedures' presentation in mathematics textbooks. The paper's secondary goal, in accordance with Zupanc and Devetak, was to look into visual representations, which proved essential also in combinatorial problem solving (Lockwood \& Gibson, 2016). The research showed combinatorial problems are insufficiently motivated in the analysed textbooks. Graphical representations are rare and lack diversity. Moreover, learners are not encouraged to create their own graphical representations. One textbook was identified to stand out. It contains prompts 
for creating personalised representations, works purposefully with isomorphic problems and encourages the reader to generalise specific procedures. In accordance with the aforementioned papers' implications, this textbook could serve as a model for other textbooks, at least in this respect.

A study standing on the borderline of teacher- and student-focused analysis was conducted by Vojiŕ and Rusek, who focused on the role of teacher's books and workbooks. Compared to the other papers included in the special issue, this research used a questionnaire survey. Whereas $63 \%$ of respondents considered workbooks important for education, $4 \%$ reported frequent use of a teacher's book with only $24 \%$ mentioning their occasional use. The results showed workbooks are, according to expectations, mostly being used at the end of lessons and as a source of homework. However, interestingly, a considerable share of teachers mentioned the use of workbooks for lesson preparation, which supported Erol's (2017) finding about workbooks being considered a type of textbook due to their mostly informative content. The absence of a teacher's book, probably as a result of publishers' market surveys, together with teachers' considerable reluctance to use a teacher's book even when available, revealed their approach to teaching preparation. It seems teachers search for educational content or even methods in a textbook (Lepik et al., 2015; Sikorová, 2005) without being interested in the explanation of goals and methods' explanation and the rationale of further topics' conception. The authors confirmed teachers' traditional approach towards lesson preparation built mostly on subject-matter transfer with only a limited focus on student activity.

The last paper included in the special issue also focused on chemistry textbooks, however, stands out with its focus which is transferable to other fields within STEM but also others. Tóthová and Rusek performed a literature review focused on the use of eye-tracking methodology on chemistry textbooks' evaluation. This technology has found various use not only in science education research (Lai et al., 2013) and provides closer insight into students' reading patterns, problems with text-graphics combination, suitability of a platform (e-books vs. traditional textbooks) and the effect of textbook component placement on the distribution of students' visual attention. It is reasonable to expect more research with such methodology to instruct textbook creation in the future. For the time being, several key findings can help teachers to use textbooks efficiently, teacher trainers to direst pre-service teachers towards more effective textbook use and textbook authors to structure the chapters of new textbooks in a more suitable manner.

The papers included in this special issue thus showed several different angles disclosing certain textbook sets' aspects which need a special attention. Although focused only on narrow aspects (e.g. phylogenetic trees, visual representations in electrolyte chemistry or presenting combinatorial concepts), the research has the potential to guide similar research within the fields covering other topics or aspects. The special issue also contains a look at the other textbook-set components focusing on the use of workbooks and teacher's books providing information useful for publishers but also for chemistry educators or researchers in the field as it provides indirect information about the conception of chemistry teaching. Last but not least, the use of hi-tech equipment which is also becoming popular in education research eye-tracking - is a pioneering attempt to promote this method among actors within textbook research or production.

This special issue's mission is to enhance further research on textbooks in order to provide a medium which teachers could rely on and which would reflect modern evidence-based trends in education. I hope that readers feel their time is well spent, that researchers and textbook authors can find a lot of inspiration and that the papers' authors receive a lot of positive feedback, including prestigious citations.

Martin Rusek

Special issue's editor

\section{Literatura}

Dees, J., Momsen, J. L., Niemi, J., \& Montplaisir, L. (2014). Student Interpretations of Phylogenetic Trees in an Introductory Biology Course. CBE - Life Sciences Education, 13(4), 666-676. https://doi.org/10.1187/cbe.14-01-0003

Erol, H. (2017). An evaluation on functionality of the workbook for social studies for the 7th graders. Pegem Egitim ve Ogretim Dergisi = Pegem Journal of Education and Instruction, 7(1), 1-22. https://doi.org/10.14527/pegegog.2017.001

Halverson, K. L., Pires, C. J., \& Abell, S. K. (2011). Exploring the complexity of tree thinking expertise in an undergraduate systematics course. Science Education, 95(5), 794-823. https://doi.org/10.1002/sce.20436

Harrison, A. G. (2001). How do teachers and textbook writers model scientific ideas for students? Research in Science Education, 31, 401-435. https://doi.org/10.1023/A:1013120312331

Hejný, M. (2012). Exploring the cognitive dimension of teaching mathematics through scheme-oriented approach to education. Orbis scholae, 6(2), 41-55. https://doi.org/10.14712/23363177.2015.39 
Chiappetta, E. L., \& Fillman, D. A. (2007). Analysis of five high school biology textbooks used in the United States for inclusion of the nature of science. International Journal of Science Education, 29(15), 1847-1868. https://doi.org/10.1080/09500690601159407

Jian, Y.-C. (2021). The immediate and delayed effects of text-diagram reading instruction on reading comprehension and learning processes: evidence from eye movements. Reading and Writing, 34(3), 727-752. https://doi.org/10.1007/s11145-020-10089-3

Johnstone, A.H. (1991). Why is science difficult to learn? Things are seldom what they seem. Journal of Computer Assisted Learning, 7(2), 75-83. https://doi.org/10.1111/j.1365-2729.1991.tb00230.x

Lai, M. L., Tsai, M. J., Yang, F. Y., Hsu, C. Y., Liu, T. C., Lee, S. W. Y., Lee, M. H., Chiou, G. L., Liang, J. C., \& Tsai, C. C. (2013). A review of using eye-tracking technology in exploring learning from 2000 to 2012. Educational Research Review, 10, 90-115. https://doi.org/10.1016/j.edurev.2013.10.001

Lepik, M., Grevholm, B., \& Viholainen, A. (2015). Using textbooks in the mathematics classroom - the teachers' view Nordic Studies in Mathematics Education, 20(3-4), 129-156. http://arkiv.ncm.gu.se/node/7993

Lockwood, E., \& Gibson, B. R. (2016). Combinatorial tasks and outcome listing: Examining productive listing among undergraduate students. Educational Studies in Mathematics, 91(2), 247-270.

https://doi.org/10.1007/s10649-015-9664-5

Mullis, I. V., Martin, M. O., Foy, P., \& Arora, A. (2012). TIMSS 2011 international results in mathematics. TIMSS \& PIRLS International Study Center. https://timss.bc.edu/timss2011/downloads/T11_IR_Mathematics_FullBook.pdf

Sikorová, Z. (2005). Transforming curriculum as teacher's activity. In M. Horsley, S. V. Knudsen, \& S. Selander (Eds.), Has Past Passed? Textbooks and Educational Media for the 21st Century (pp. 256-261). Stockholm Institute of Education Press.

Son, J.-W., \& Kim, O.-K. (2015). Teachers' selection and enactment of mathematical problems from textbooks. Mathematics Education Research Journal, 27(4), 491-518. https://doi.org/10.1007/s13394-015-0148-9

Šubová, S. (2020). Analýza didaktické vybavenosti učebnic chemie pro základní školy v ČR [Analysis of Czech lower-secondary school chemistry textbooks' didactical equipment] [Diplomová práce, Univerzita Karlova, Pedagogická fakulta, katedra chemie a didaktiky chemie]. Praha.

Taber, K. S. (2013). Revisiting the chemistry triplet: drawing upon the nature of chemical knowledge and the psychology of learning to inform chemistry education. Chemistry Education Research and Practice, 14(2), 156-168. https://doi.org/10.1039/C3RP00012E

Talanquer, V. (2011). Macro, submicro, and symbolic: the many faces of the chemistry "triplet". International Journal of Science Education, 33(2), 179-195. https://doi.org/10.1080/09500690903386435

Vojír, K., \& Rusek, M. (2021). Preferred Chemistry Curriculum Perspective: Teachers' Perception of Lower-Secondary School Textbooks. Journal of Baltic Science Education, 20(2), 316-331.

https://doi.org/10.33225/jbse/21.20.00 